\title{
PREPOSISI BAHASA CIACIA DI DESA WABULA KECAMATAN WABULA KABUPATEN BUTON
}

\author{
Asrul Nazar \\ Program Studi Pendidikan Bahasa dan Sastra Indonesia, \\ Fakultas Keguruan dan Ilmu Pendidikan, \\ Universitas Muhammadiyah Buton, Jl. Betoambari No. 36 Baubau. \\ E-mail:asrulnazar@gmail.com
}

\begin{abstract}
Abstrak
Tujuan penelitian ini adalah untuk mengetahui bentuk preposisi bahasa Ciacia di Desa Wabula, Kecamatan Wabula, Kabupaten Buton. Metode yang digunakan dalam penelitian ini adalah metode deskriptif. Data penelitian ini adalah data bahasa lisan berupa tuturan-tuturan dalam bentuk frasa, klausa, atau kalimat bahasa Ciacia di Desa Wabula yang menunjukkan bentuk dan Arti Preposisi Bahasa Ciacia Desa Wabula Kecamatan Wabula Kabupaten Buton. Hasil penelitian ini menunjukan bahwa bentuk preposisi Bahasa Ciacia di Desa Wabula Kecamatan Wabula Kabupaten Buton terdiri atas (1) preposisi monomorfemis dan (2) preposisi polimorfemis. Preposisi monomorfemis Bahasa Ciacia di Desa Wabula Kecamatan Wabula Kabupaten Buton, yaitu kata daso 'untuk/buat', mina 'dari', $i$ ' $\mathrm{ke}^{\prime}, i$ 'di, pada', mi 'dengan' dan aso 'tentang. Preposisi tersebut terletak di awal frasa dan diikuti unsur nomina dan verba. Sedangkan preposisi polimorfemis Bahasa Ciacia di Desa Wabula Kecamatan Wabula Kabupaten Buton, mencakup (a) preposisi berafiks, (b) preposisi gabungan. Preposisi berafiks , meliputi poasa-asa 'bersama', nokoisamo 'menjelang', dan norope 'menuju'. Unsur yang mengikuti preposisi ini berupa nomina dan verba. Preposisi gabungan preposisi pada kata $i$ wawo 'di atas', $i$ woru 'di bawah', $i$ haroa 'di depan', $i$ lalo 'ke dalam', dan $i$ taliku 'di belakang', $i$ lepe 'dari samping', dan mina i lalo 'dari dalam', rampano 'oleh sebab', dan rato 'sampai dengan'. Preposisi berafiks maupun preposisi gabungan tersebut umumnya diikuti unsur nomina dan verba.
\end{abstract}

Kata kunci: linguistik, preposisi, Ciacia.

\begin{abstract}
The purpose of this research is to know form of preposition of Ciacia language in Wabula Village, Wabula Sub-district, Buton Regency. The method used in this research is descriptive method. This research data is oral language data in the form of speech-speech in the form of phrase, clause, or sentence of Ciacia language in Wabula Village which shows form and Meaning of Ciacia Language Preposition Wabula Village Wabula Sub-district of Buton Regency. The results of this study indicate that the preposition form of Ciacia Language in Wabula Village Wabula Sub-district of Buton Regency consists of (1) preposition monomorfemis and (2) polymorphism preposition. The preposition of monomorfemis The Ciacian language in Wabula Village Wabula Sub-district of Buton District, ie the word daso 'to/create', mina 'from', $i$ 'ke', $i$ 'di, on', mi 'with' and aso 'about. The preposition lies at the beginning of the phrase and is followed by the noun and verb elements. While the polymorphism preposition of the Ciacian Language in Wabula Village, Wabula Sub-district of Buton Regency, includes (a) a beraphical preposition, (b) a joint preposition. Bapepamy prepositions, including 'joint', 'nokoisamo' approaching ', and norope' toward'. The elements that follow this preposition are nouns and verbs. Preposition of composite preposition in the word $i$ wawo 'above', $i$ woru 'below', haroa 'in front', lalo 'into', and $i$ taliku 'behind', i lepe 'from side', and mina I lalo 'from within', rampano 'by cause', and rato 'up to'. The berechetic preposition and the combined preposition are generally followed by noun and verbs.
\end{abstract}

Keywords: linguistics, preposition, Ciacia. 


\section{SANG PENCERAH}

Volume 2, Nomor 2, Agustus 2016, Hlm. 1-8

Asrul Nazar: Preposisi Bahasa Ciacia di Desa Wabula ...

\section{Pendahuluan}

Di Indonesia terdapat sejumlah suku dan daerah yang memiliki rumpun bahasa yang berbeda-beda. Hal itu mengakibatkan terjadinya kontak yang sangat intensif antara bahasa Indonesia dengan bahasa daerah. Bahasa Indonesia sebagai bahasa pemersatu bangsa memiliki empat fungsi besar yaitu (1) sebagai alat untuk menyatakan ekspresi diri; (2) sebagai alat komunikasi; (3) sebagai alat untuk mengadakan integrasi dan adaptasi sosial; dan (4) sebagai alat untuk mengadakan kontrol sosial (Keraf, 2001:3).

Mengingat pentingnya bahasa daerah sebagai pendukung bahasa Indonesia sekaligus pendukung kebudayaan nasional, kegiatan pengkajian bahasa daerah tidak hanya menjadi tanggung jawab pemerintah, tetapi juga menjadi tanggung jawab kita semua, terutama masyarakat pengguna bahasa itu sendiri. Oleh karena itu, pembinaan dan pengembangan bahasa daerah melalui berbagai kegiatan penelitian sangat penting artinya karena hal itu tidak saja penting dalam rangka memperkaya perbendaharaan kosakata bahasa Indonesia, tetapi yang tidak kalah penting dari itu adalah mengukuhkan persatuan dan kesatuan bangsa serta dapat menanamkan rasa saling menghargai antarsesama warga negara.

Keraf (1984:20) mengemukakan bahwa dalam masa perkembangan dan pembangunan ini, bahasa-bahasa daerah masih amat diperlukan untuk (a) memperkaya bahasa Indonesia, terutama dalam memperkaya perbendaharaan kata dan bentuk kata; (b) mengenal berbagai macam faktor penting yang menentukan corak struktur masyarakat Indonesia; dan (c) mengenal kesusastraannya. Bahkan pengenalan terhadap berbagai bahasa daerah, turut pula meletakkan dasar yang kuat bagi tegaknya persatuan dan kesatuan bangsa serta dapat menanamkan rasa saling menghargai yang sedalam-dalamnya. Kegiatan penelitian terhadap bahasa-bahasa daerah yang dilakukan oleh para peneliti selama ini merupakan salah satu wujud dari upaya pembinaan dan pengembangan bahasa daerah. Kegiatan penelitian seperti ini dilakukan untuk melestarikan bahasa daerah yang terancam kepunahan. Para ahli bahasa memunyai pandangan yang berbedabeda tentang masalah kata depan. Istilah yang digunakan untuk menyebutnya pun berbeda-beda.

Keraf (1984: 90) menggunakan istilah preposisi. Preposisi menurut Keraf dapat ditentukan berdasarkan ciri morfologis dan ciri sintaksis. Secara morfologis pada umumnya kata preposisi sukar sekali mengalami perubahan bentuk, dan secara sintaksis kata golongan ini tidak dapat menduduki fungsi subjek, predikat, dan objek, melainkan berfungsi untuk memperluas atau mengadakan transformasi kalimat. Dalam penelitian ini digunakan istilah preposisi karena sudah sangat lazim digunakan di lingkungan pengajaran tata bahasa Indonesia di sekolah-sekolah. Pembicaraan tentang kata depan atau preposisi, khususnya preposisi bahasa Ciacia belum ada, baik penelitian sebelumnya maupun penelitian yang sedang berlangsung. Khusus bahasa Ciacia yang berada di Kecamatan Wabula perlu mendapat penganganan segera karena penutur bahasa Ciacia di Desa ini berdampingan dengan penutur bahasa Indonesia oleh generasi yang sudah dan sedang mengikuti pendidikan di sekolah formal. Dengan demikian upaya peneliti dalam membahas tentang preposisi ini merupakan wujud upaya serius untuk mempertahankan bahasa Ciacia ini dalam menghadapi tantangan kepunahan.

Kemajuan teknologi termasuk teknologi komunikasi merupakan tantangan serius dalam memertahankan keaslian bahasa-bahasa daerah di Indonesia, termasuk tantangan bahasa daerah Ciacia di Desa Wabula Kecamatan Wabula Kabupaten Buton. Suatu keuntungan yang mampu 


\section{SANG PENCERAH}

Volume 2, Nomor 2, Agustus 2016, Hlm. 1-8

Asrul Nazar: Preposisi Bahasa Ciacia di Desa Wabula ...

memerkuat eksistensi bahasa Daerah Ciacia ini adalah fungsinya dalam penyelenggaraan kebudayaan masih tetap menggunakan bahasa daerah ini sendiri yaitu bahasa Ciacia. Akan tetapi, belum memberi kenyamanan bagi pemerhati bahasa daerah, karena hal tersebut belum apa payung hukumnya dalam bentuk peraturan dearah. Berdasarkan uraian di atas, fokus penelitian ini adalah bagaimana bentuk preposisi bahasa Ciacia di Desa Wabula, Kecamatan Wabula, Kabupaten Buton?

Tujuan penelitian ini adalah untuk mengetahui bentuk preposisi bahasa Ciacia di Desa Wabula, Kecamatan Wabula, Kabupaten Buton.

\section{Metode Penelitian}

\section{Metode dan Jenis Penelitian}

Metode yang digunakan dalam penelitian ini adalah metode deskriptif. Metode deskriptif yang digunakan dalam penelitian ini adalah berhubungan langsung dengan pengumpulan data, pengkajian data, dan penyusunan laporan hasil penelitian. Penggunaan metode ini bertujuan membuat deskripsi yang sistematis dan akurat mengenai data, sifat-sifat, serta hubungan fenomena-fenomena yang diteliti (Djajasudarma, 1993:8). Dari jenisnya, penelitian ini termasuk penelitian lapangan. Dikatakan penelitian lapangan karena keseluruhan data yang dikumpulkan umumnya diperoleh di lapangan, yakni melalui tuturan informan.

\section{Data dan Sumber Data}

Data penelitian ini adalah data bahasa lisan berupa tuturan-tuturan dalam bentuk frasa, klausa, atau kalimat bahasa Ciacia di Desa Wabula yang menunjukkan bentuk dan Arti Preposisi Bahasa Ciacia Desa Wabula Kecamatan Wabula Kabupaten Buton. Data ini diperoleh dari data cerita, data klasifikasi dan data buatan. Terkait dengan data yang dikemukakan di atas, maka sumber data yang digunakan dalam penelitian ini adalah berupa data lisan dari para penutur asli bahasa Ciacia Desa Wabula yang berdomisili di Desa Wabula Kecamatan Wabula Kabupaten Buton. Untuk itu, dipilih tiga orang informan, yakni satu orang sebagai informan utama dan dua orang sebagai informan tambahan.

Ketiga informan tersebut di atas, ditetapkan dengan kriteria sebagai berikut (1) Penutur asli bahasa Ciacia Desa Wabula yang berdomisili di Desa Wabula Kecamatan Wabula Kabupaten Buton; (2) Jarang meninggalkan lokasi bahasa yang bersangkutan; (3) Memiliki artikulasi yang normal; (4) Berusia sekitar 40 tahun sampai dengan 60 tahun; dan (5) Komunikatif sehingga mudah memahami apa yang diajukan peniliti (Konisi, 1999:6).

\section{Teknik Pengumpulan Data}

Metode yang digunakan untuk mengumpulkan data penelitian ini adalah metode cakap dan simak. Metode cakap adalah suatu metode yang digunakan dengan melakukan kontak antara peneliti (selaku peneliti) dan penutur selaku nara sumber atau informan (Mahsun, 2005:95). Metode cakap tersebut diikuti pula dengan motode simak, yaitu suatu metode yang digunakan oleh peneliti dengan cara menyimak penggunaan bahasa yang dituturkan oleh informan (Mahsun, 2005:92). Teknik yang digunakan dalam penelitian adalah teknik rekam dan teknik catat (Mahsun, 2005: 131-132).

Penggunaan teknik rekam didasarkan pada pertimbangan bahwa data yang diteliti adalah berupa data lisan. Sehingga dapat dilakukan, baik dengan berencana dan sistematis maupun dengan serta merta (sadap rekam). Dengan demikian, teknik rekam merupakan teknik utama bagi pengumpulan data penelitian ini, sedangkan teknik catat hanya sebagai koreksi terhadap hasil rekaman yang kurang jelas. Selain itu, 


\section{SANG PENCERAH}

Volume 2, Nomor 2, Agustus 2016, Hlm. 1-8

Asrul Nazar: Preposisi Bahasa Ciacia di Desa Wabula ...

setelah data terkumpul, peneliti juga menggunakan teknik introspeksi melalui teknik elisitasi. Teknik intropeksi tersebut digunakan mengingat peneliti juga adalah penutur asli bahasa Ciacia Desa Wabula yang berdomisili di Desa Wabula Kecamatan Wabula Kabupaten Buton.

\section{Teknik Analisis Data}

Dalam penganalisisan data, penelitian ini menggunakan pendekatan struktural dan pendekatan semantik. Penggunaan kedua jenis pendekatan ini sesuai dengan objek penelitian, yakni preposisi bahasa Ciacia Desa Wabula yang berdomisili di Desa Wabula Kecamatan Wabula Kabupaten Buton yang dikaji dari aspek bentuk dan makna (arti). Kedua pendekatan tersebut digunakan sejalan dengan pandangan Sausure yang menyatakan bahwa bahasa merupakan sistem yang unsur-unsurnya saling berhubungan untuk membentuk satu kesatuan makna yang utuh (Djajasudarma, 1993:60). Oleh karena itu, baik pendekatan struktural maupun pendekatan semantik kedua-duanya dapat diterapkan ke dalam metode kajian aspek linguistik, termasuk pula kajian preposisi bahasa Ciacia Desa Wabula yang berdomisili di Desa Wabula Kecamatan Wabula Kabupaten Buton.

Metode kajian aspek linguistik yang dimaksud adalah metode kajian distribusional atau metode agih (oposisi dari metode kajian padan) menggunakan alat penentu unsur bahasa sendiri (Konisi, 2000: 38). Metode agih memiliki teknik dasar yang disebut teknik pilah unsur langsung (PUL), yaitu memilah data berdasarkan satuan lingual menjadi beberapa bagian atau unsur. Unsur-unsur ini selanjutnya dipandang sebagai bagian atau unsur yang langsung membentuk satuan lingual yang lebih besar.

\section{Pembahasan}

\section{Bentuk Preposisi Bahasa Ciacia di Desa Wabula}

Preposisi Bahasa Ciacia di Desa Wabula Kecamatan Wabula Kabupaten Buton terdiri atas dua bentuk, yakni preposisi monomorfemis dan polimorfemis. Gambaran mengenai kedua bentuk preposisi Bahasa Ciacia di Desa Wabula tersebut dapat diikuti pada paparan berikut ini.

\section{Preposisi Monomorfemis}

Preposisi monomorfemis adalah preposisi yang terdiri hanya atas satu morfem dan karena itu tidak dapat diperkecil lagi bentuknya. Bentuk preposisi seperti ini dalam Bahasa Ciacia di Desa Wabula Kecamatan Wabula Kabupaten Buton perhatikan tabel di bawah ini.

Tabel 1 Bentuk Preposisi Monomorfemis Bahasa Ciacia di Desa Wabula Kecamatan Wabula Kabupaten Buton

\begin{tabular}{|c|c|}
\hline $\begin{array}{c}\text { Preposisi } \\
\text { Monomorfemis }\end{array}$ & Contoh Kalimat \\
\hline daso 'untuk' & $\begin{array}{l}\text { Taepa nibawano La Ama } \underline{\text { daso }} \text { indau. } \\
\text { 'Mangga yang di bawah ayah ini } \\
\text { untuk saya'. }\end{array}$ \\
\hline daso 'buat' & $\begin{array}{l}\text { Indau bawa baju daso Wa Fadah. } \\
\text { 'Saya membawa baju buat Wa } \\
\text { Wadah. }\end{array}$ \\
\hline daso 'oleh' & $\begin{array}{l}\text { Bajuu nopideue daso Ratna. } \\
\text { 'Bajuku dijahit oleh Ratna'. }\end{array}$ \\
\hline mina 'dari' & $\begin{array}{l}\text { La Ompu katamo nombule mina } \\
\text { Baubau. } \\
\text { 'Kakek baru pulang dari Bau-bau'. }\end{array}$ \\
\hline mina 'sejak' & $\begin{array}{l}\text { Amano nowilaka mina i wawala. } \\
\text { 'Ayahnya pergi sejak tadi pagi'. }\end{array}$ \\
\hline$i{ }^{\prime} \mathrm{ke}^{\prime}$ & $\begin{array}{l}\text { Indau sadia inte } \underline{i} \text { kaanano Wa Ompu. } \\
\text { 'Saya selalu pergi ke rumah nenek'. }\end{array}$ \\
\hline$i^{\prime} \mathrm{di}^{\prime}$ & $\begin{array}{l}\text { Indau hora } i \text { Wabula. } \\
\text { 'Saya tinggal di Wabula'. }\end{array}$ \\
\hline$i$ 'pada' & $\begin{array}{l}\text { Kamanu-manu ancu no tae } \underline{\boldsymbol{i}} \text { raha sau. } \\
\text { 'Burung itu bertengger pada ranting } \\
\text { kayu' }\end{array}$ \\
\hline mi 'dengan' & $\begin{array}{l}\text { Indau oburi mi pake pena. } \\
\text { Saya menulis dengan pulpen. }\end{array}$ \\
\hline aso 'tentang' & $\begin{array}{l}\text { La Ompu pikoja-koja aso pengalamano. } \\
\text { 'Kakekku menceritakan tentang } \\
\text { pengalamannya' }\end{array}$ \\
\hline
\end{tabular}




\section{SANG PENCERAH}

Volume 2, Nomor 2, Agustus 2016, Hlm. 1-8

Asrul Nazar: Preposisi Bahasa Ciacia di Desa Wabula ...

Data di atas, menjelaskan bahwa dalam bahasa Bahasa Ciacia di Desa Wabula Kecamatan Wabula Kabupaten Buton terdapat preposisi 'daso' yang mengandung arti peruntukkan. Preposisi kata mina yang menandai hubungan asal, arah dari suatu tempat dan preposisi ' $i$ ' yang menandakan hubungan tempat berada dan yang menandai hubungan waktu dari saat yang satu ke saat yang lain. Preposisi kata ' $m i$ ' yang menandakan hubungan cara. Preposisi kata 'aso'yang menandakan hubungan ikhwal atau peristiwa. Preposisi monomorfemis terletak dibagian awal frasa dan unsur yang mengikutinya adalah nomina dan verba.

\section{Preposisi Polimorfemis}

Preposisi polimorfemis adalah preposisi yang dibentuk dengan memakai afiks atau dengan menggabungkan dua kata atau lebih. Bahasa Ciacia di Desa Wabula Kecamatan Wabula Kabupaten Buton, preposisi yang demikian terdiri atas dua jenis, yaitu (1) preposisi berafiks dan (2) preposisi gabungan.

\section{a. Preposisi Berafiks}

Preposisi berafiks adalah preposisi yang dibentuk dengan menempelkan afiks pada dasar.

Perhatikan tabel berikut.

Tabel 2 Bentuk Preposisi Polimorfemis Berafiks Bahasa Ciacia di Desa Wabula Kecamatan Wabula Kabupaten Buton

\begin{tabular}{|c|c|}
\hline $\begin{array}{c}\text { Preposisi } \\
\text { Polimoremis } \\
\text { Berafiks }\end{array}$ & Contoh Kalimat \\
\hline $\begin{array}{l}\text { nokoisamo } \\
\text { 'menjelang' }\end{array}$ & $\begin{array}{l}\text { Hamoia rato } i \text { Tolando nokoisamo } \\
\text { morondo. } \\
\text { 'Mereka tiba di Tolando menjelang } \\
\text { malam'. }\end{array}$ \\
\hline $\begin{array}{l}\text { poasa-asa } \\
\text { 'bersama' }\end{array}$ & $\begin{array}{l}\text { La Ali nomaa poasa-asa mi La Adi. } \\
\text { 'La Ali makan bersama dengan La } \\
\text { Adi'. }\end{array}$ \\
\hline $\begin{array}{l}\text { norope } \\
\text { 'menuju' }\end{array}$ & $\begin{array}{l}\text { Hamoia norope i ka akanamu. } \\
\text { 'Mereka menuju ke rumahmu'. }\end{array}$ \\
\hline
\end{tabular}

Berdasarkan data ini terdapat preposisi polimorfemis berafiks Bahasa Ciacia di Desa Wabula Kecamatan Wabula Kabupaten Buton, yaitu tampak pada kata nokoisumo, bentuk dasarnya adalah koisu yang artinya hampir, jelang, selanjutnya bentuk dasar tersebut dibubuhi prefiks no + koisa + mo (nokoisumo) 'menjelang'. selanjutnya tampak pada kata poasa-asa, berasal dari kata dasar asa-asa yang artinya sama-sama, kemudian dilekatkan dengan prefiks po- sehingga menjadi poasa-asa yang artinya bersama-sama/bersama. Data selanjutnya pada kata norope, berasal dari kata dasar rope, yang artinya arah, kemudian bentuk dasar ini dibubuhi prefiks no- menjadi norope yang artinya menuju. Unsur preposisi monomorfemis ini adalah nomina dan verba.

\section{b. Preposisi Gabungan}

Preposisi polimorfemis gabungan kata adalah berupa preposisi gabungan preposisi dengan preposisi atau dapat juga merupakan gabungan preposisi dengan yang bukan preposisi. Perhatikan tabel berikut.

Tabel 3 Bentuk Preposisi Polimorfemis Gabungan Bahasa Ciacia di Desa Wabula Kecamatan Wabula Kabupaten Buton

\begin{tabular}{|c|c|}
\hline $\begin{array}{l}\text { Preposisi } \\
\text { Polimoremis } \\
\text { Gabungan }\end{array}$ & Contoh Kalimat \\
\hline i wawo 'di atas' & $\begin{array}{l}\text { Alasia upo buku u i iwawo meja ancu. } \\
\text { 'Ambilkan saya buku di atas meja } \\
\text { itu'. }\end{array}$ \\
\hline $\begin{array}{l}i \text { woru 'di } \\
\text { bawah' }\end{array}$ & $\begin{array}{l}\text { La Andi pikakuri-kuri i woru wurawa. } \\
\text { 'La Andi bermain-main di bawah } \\
\text { kolong'. }\end{array}$ \\
\hline $\begin{array}{l}i \quad \text { haroa 'di } \\
\text { depan' }\end{array}$ & $\begin{array}{l}\text { Indau pisi hamba bonceau upo rato } \underline{i} \\
\text { haroa ancu. } \\
\text { Saya minta tolong bonceng saya } \\
\text { sampai di depan itu. }\end{array}$ \\
\hline i taliku & Impae indau wilaka, ai-aiu nohokoloau $\underline{i}$ \\
\hline
\end{tabular}




\section{SANG PENCERAH}

Volume 2, Nomor 2, Agustus 2016, Hlm. 1-8

Asrul Nazar: Preposisi Bahasa Ciacia di Desa Wabula ...

\begin{tabular}{|c|c|}
\hline 'di belakang' & $\begin{array}{l}\text { taliku. } \\
\text { 'Kemana saya jalan, adik saya selalu } \\
\text { ikut di belakang' }\end{array}$ \\
\hline i lalo & Pamaso epo baju ancu i lalo lemari. \\
\hline 'ke dalam' & $\begin{array}{l}\text { 'Masukkan dulu baju itu ke dalam } \\
\text { lemari'. }\end{array}$ \\
\hline $\begin{array}{l}\text { mina i lepe } \\
\text { 'dari samping' }\end{array}$ & $\begin{array}{l}\text { Hamoia indau itae haleo mina i lepeno } \\
\text { kaana ancu. }\end{array}$ \\
\hline & $\begin{array}{l}\text { 'Mereka saya lihat tadi dari samping } \\
\text { rumah itu'. }\end{array}$ \\
\hline $\begin{array}{l}\text { mina i lalo } \\
\text { 'dari dalam' }\end{array}$ & $\begin{array}{l}\text { Baju bau ancu indau alae mina i lalo } \\
\text { lemari. }\end{array}$ \\
\hline & $\begin{array}{l}\text { 'Baju baru itu saya ambil dari dalam } \\
\text { lemari'. }\end{array}$ \\
\hline & Rato alo ana ciapo amindongoe kabarano. \\
\hline $\begin{array}{l}\text { 'sampai } \\
\text { dengan' }\end{array}$ & $\begin{array}{l}\text { 'Sampai dengan hari ini belum } \\
\text { terdengar kabarnya'. }\end{array}$ \\
\hline rampano & Rampano kaomelano maka nopeelue mia. \\
\hline 'oleh sebab' & $\begin{array}{l}\text { Oleh sebab kebaikannya makanya } \\
\text { disenangi orang. }\end{array}$ \\
\hline
\end{tabular}

Preposisi

polimorfemis gabungan Bahasa Ciacia di Desa Wabula Kecamatan Wabula Kabupaten Buton yang tercetak miring pada tabel di atas. Pada data kata $i$ wawo sebagai representasi contoh data di dalam tabel. Dikatakan preposisi gabungan karena kata $i$ juga merupakan preposisi monomorfemis, jadi kata $i$ wawo merupakan gabungan preposisi dengan preposisi.

Preposisi gabungan yang terletak pada awal kalimat tersebut di atas berfungsi sebagai penegas kalimat. Misalnya, pada preposisi tunggal rampano (oleh sebab) menegaskan pernyataan kebaikan seseorang kepada orang lain sehingga disenangi orang). Unsur yang mengikuti preposisi tunggal tersebut adalah umumnya berupa nomina. Dengan demikian, jelaslah bahwa Bahasa Ciacia di Desa Wabula Kecamatan Wabula Kabupaten Buton memiliki preposisi tunggal, sama halnya yang terjadi pada umumnya dalam bahasa-bahasa lainnya di Nusantara, atau bahkan dalam Bahasa Indonesia.

\section{Interpretasi Hasil Penelitian}

Preposisi Bahasa Ciacia di Desa Wabula Kecamatan Wabula Kabupaten Buton terdiri atas preposisi monomorfemis dan polimorfemis. Preposisi monomorfemis adalah preposisi yang hanya terdiri atas morfem dan karena itu tidak dapat diperkecil lagi bentuknya. Preposisi monomorfemis Bahasa Ciacia di Desa Wabula Kecamatan Wabula Kabupaten Buton seperti daso (untuk/buat), mina (dari), $i$ (ke), $i$ (di, pada), dan te (oleh) umumnya terletak di awal frasa dan diikuti oleh unsur nomina dan verba.

Preposisi monomorfemis Bahasa Ciacia di Desa Wabula Kecamatan Wabula Kabupaten Buton tersebut di atas umumnya menunjukkan arti/makna peruntukkan, asal, arah, pelaku, dan tempat berada. Preposisi monomorfemis Bahasa Ciacia di Desa Wabula Kecamatan Wabula Kabupaten Buton sebagaimana yang ditemukan dalam hasil penelitian ini pada prinsipnya sama dengan bahasa-bahasa daerah lainnya di Indonesia. Hal ini berarti pula bahwa bahasa Bahasa Ciacia di Desa Wabula Kecamatan Wabula Kabupaten Buton memiliki preposisi monomorfemis yang tidak terbatas, baik dalam komunikasi lisan maupun tertulis.

Preposisi monomorfemis Bahasa Ciacia di Desa Wabula Kecamatan Wabula Kabupaten Buton berbeda dengan preposisi polimorfemis. Dalam preposisi polimorfemis bahasa Kepualaun Tukang Besi dialek Cia-cia terdiri atas dua bagian, yaitu (1) preposisi berafiks, dan (2) preposisi gabungan. Preposisi polimorfemiks berafiks dibentuk dengan menempelkan afiks pada dasar morfem bebas ataupun morfem terikat. Bentuk preposisi itu dalam Bahasa Cia-Cia di Desa Wabula Kecamatan Wabula Kabupaten Buton adalah poasa-asa (bersama), nokoisumo (menjelang), dan atenga (bagaikan/seperti). Unsur yang mengikuti preposisi ini umumnya berupa nomina dan verba, 


\section{SANG PENCERAH}

Volume 2, Nomor 2, Agustus 2016, Hlm. 1-8

Asrul Nazar: Preposisi Bahasa Ciacia di Desa Wabula ...

sedangkan arti yang terkandung di dalamnya menandai hubungan kesertaan, waktu sebelum dan kemiripan.

Keberadaan preposisi polimorfemis berafiks di atas juga sama dengan preposisi gabungan. Bedanya, preposisi polimorfemis berafiks mendapat afiks (prefiks atau sufiks), sedangkan preposisi gabungan terdiri atas dua preposisi atau merupakan gabungan preposisi dengan kata lain. Preposisi gabungan preposisi dengan preposisi, misalnya dapat dilihat pada kata labicungkee (daripada), rampano (oleh sebab), dan rato (sampai dengan), sedangkan preposisi gabungan preposisi dengan kata lain dapat dilihat pada kata $i$ wawo (di atas), $i$ woru (di bawah), $i$ haroa (di depan), $i$ lalo (ke dalam), dan $i$ taliku (di belakang), mina $i$ lepe (dari samping), dan mina $i$ lalo (dari dalam). Preposisi gabungan tersebut umumnya diikuti unsur nomina dan verba. Preposisi majemuk umumnya menandai arti/makna hubungan perbandingan, sebab, dan batas waktu tertentu, sedangkan preposisi gabungan menandai arti/makna hubungan arah, dan asal.

Dari uraian di atas dapat diinterpretasikan bahwa preposisi Bahasa Cia-Cia di Desa Wabula Kecamatan Wabula Kabupaten Buton pada prinsipnya memiliki bagian dan distribusi yang sama dengan bahasa-bahasa lainnya di Indonesia, yaitu terdiri atas (1) preposisi monomorfemis yang unsur-unsurnya diikuti oleh nomina, dan verba (2) preposisi polimorfemis, yang meliputi (a) preposisi berafiks dan (b) preposisi gabungan.

\section{Simpulan}

Simpulan penelitian ini bahwa bentuk preposisi Bahasa Ciacia di Desa Wabula Kecamatan Wabula Kabupaten Buton terdiri atas (1) preposisi monomorfemis dan (2) preposisi polimorfemis. Preposisi monomorfemis Bahasa Ciacia di Desa Wabula Kecamatan Wabula Kabupaten
Buton, yaitu kata daso 'untuk/buat', mina 'dari', $i$ 'ke', $i$ 'di, pada', mi 'dengan' dan aso 'tentang. Preposisi tersebut terletak di awal frasa dan diikuti unsur nomina dan verba. Sedangkan preposisi polimorfemis Bahasa Ciacia di Desa Wabula Kecamatan Wabula Kabupaten Buton, mencakup (a) preposisi berafiks, (b) preposisi gabungan. Preposisi berafiks , meliputi poasa-asa 'bersama', nokoisamo 'menjelang', dan norope 'menuju'. Unsur yang mengikuti preposisi ini berupa nomina dan verba. Preposisi gabungan preposisi pada kata $i$ wawo 'di atas', $i$ woru 'di bawah', i haroa 'di depan', i lalo 'ke dalam', dan $i$ taliku 'di belakang', i lepe 'dari samping', dan mina $i$ lalo 'dari dalam', rampano 'oleh sebab', dan rato 'sampai dengan'. Preposisi berafiks maupun preposisi gabungan tersebut umumnya diikuti unsur nomina dan verba.

\section{Daftar Pustaka}

Alwi, Hasan, dkk. 2003. Tata Bahasa Baku Bahasa Indonesia (Edisi Ketiga). Jakarta: Balai Pustaka.

Chaer, Abdul. 1987. Tata Bahasa Praktis Bahasa Indonesia. Jakarta: Bharata.

Depdikbud. 2003. Kamus Besar Bahasa Indonesia. Jakarta: Balai Pustaka.

Djajasudarma, T. Fatima. 1993. Metode Linguistik (Rancangan Metode Penelitian dan Kajian). Jakarta: Gramedia Pustaka Utama.

Finoza, Lamuddin. 2005. Komposisi Bahasa Indonesia. Jakarta: Diksi Insan Media.

Keraf, Gorys. 1984. Tata Bahasa Indonesia. Jakarta: Nusa Indah.

Nusa Indah. 


\section{SANG PENCERAH}

Volume 2, Nomor 2, Agustus 2016, Hlm. 1-8

Asrul Nazar: Preposisi Bahasa Ciacia di Desa Wabula ...

Konisi, La Yani. 1999. Data dan Sumber Data dalam Penelitian Linguistik: Semiotika. Kendari: FKIP Unhalu. (Materi Pokok Perkuliahan Penelitian Bahasa). Kendari: FKIP Unhalu.

Kridalaksana, Harimurti. 2012. Kamus Linguistik Edisi V. Jakarta: Gramedia.

Mahsun. 2005. Metode Penelitian Bahasa. Jakarta: PT Raja Grafindo Persada

Ramlan. M. 1987. Kata Depan atau Preposisi dalam Bahasa Indonesia. Yogyakarta: Karyono.

Wirjosoedarmo, Soekono. 1984. Tata Bahasa Bahasa Indonesia (Edisi Lengkap). Surabaya: Sinar Wijaya. 